\title{
Uridine diphosphoglucose dehydrogenase activity in synovial lining cells in the experimental antigen induced model of rheumatoid arthritis: an indication of synovial lining cell function
}

\author{
A A Pitsillides, S M Blake
}

\begin{abstract}
Uridine diphosphoglucose dehydrogenase (UDPGD) is the enzyme responsible for the production of uridine diphospho(UDP)glucuronate, an essential monosaccharide in the biosynthesis of hyaluronan, which is found in high concentrations in normal synovial fluid. Synovial lining cells have been implicated in the synthesis of hyaluronan, but the degree to which they are adapted metabolically to this function in normal and inflamed synovium has not been established. Using a quantitative cytochemical method it was shown that synovial lining cells from chronically inflamed rabbit synovium had significantly lower UDPGD activity per cell than the lining cells of normal synovium. These findings suggest that the lining cells of normal non-inflamed synovium may be enzymatically adapted for the synthesis of hyaluronan and that this may be an indication of a specific role of synovial lining cells in the maintenance of normal joint function.
\end{abstract}

(Ann Rheum Dis 1992; 51: 992-995)

As emphasised by Fraser and Laurent ${ }^{1}$ hyaluronan is found at particularly high concentrations in the synovial fluid of normal diarthrodial joints and it has been suggested that it may be responsible for the intrinsic viscoelastic properties which are characteristic of this fluid. ${ }^{2}$ For some time rheumatologists have observed that the viscosity of synovial fluid markedly decreases in the presence of inflammation ${ }^{3}$ and it has been shown that the synovial fluid of rheumatoid arthritic joints contains concentrations of hyaluronan lower than those found in the synovial fluid of normal joints. ${ }^{4}$ However, it still remains controversial whether this alteration in the concentration of hyaluronan is mediated by dilution, degradation, or altered synthesis of hyaluronan. Furthermore, although synovial lining cells have been implicated in the maintenance of these levels of hyaluronan, ${ }^{5}$ the degree to which individual cells in normal and rheumatoid synovial lining are adapted metabolically to the synthesis of this glycosaminoglycan has not been established. ${ }^{6}$

Hyaluronan molecules are long, unbranched polysaccharides composed of repeating disaccharide units of glucuronic acid linked to $\mathrm{N}$ acetyl glucosamine, ${ }^{7}$ synthesised by alternate transfer of the substrates, namely uridine diphospho(UDP)-glucuronic acid and UDP- $N$ acetyl glucosamine, to nascent hyaluronan chains by hyaluronan synthase. ${ }^{8}$ UDP-glucuronic acid is a key monosaccharide in the synthesis of hyaluronan and sulphated glycosaminoglycans. Uridine diphosphoglucose dehydrogenase (UDPGD; UDP-glucose: $\mathrm{NAD}^{+}$oxidoreductase; EC. 1.1.1.22) is the enzyme responsible for the non-reversible conversion of UDP-glucose to UDP-glucuronic acid and it has been suggested that UDPGD activity may be the rate limiting step in the production of UDP-glucuronate. ${ }^{10}$ The assessment of enzyme activity in an individual cell population, within a tissue such as synovium, is difficult to achieve by conventional biochemical procedures for two reasons: firstly, the synovial lining cells of normal synovium constitute too small a population for conventional biochemical assays; and secondly, lining cells in chronically inflamed joints constitute a small fraction of the total cells, as many infiltrating cells comprise the excessive outgrowths of the lining which is characteristic of this disease. It was therefore necessary to use the techniques of quantitative cytochemistry ${ }^{11}$ to assess enzyme activity in individual synovial lining cells in situ.

The immunological induction of an experimental arthritis in the knees of rabbits ${ }^{12} 13$ is well established as a model of human rheumatoid arthritis. ${ }^{14}$ The model produces a chronic monarticular arthritis which closely resembles human rheumatoid arthritis in synovial histopathology and in biochemical changes associated with the synovial lining cells. ${ }^{6}{ }^{5} 16$ We have used a newly adapted quantitative cytochemical method $^{17}$ to assess the UDPGD activity as a measure of the enzymatic machinery necessary for the production of one of the essential monosaccharides of hyaluronan in the synovial lining cells of normal and inflamed knees in the antigen induced rabbit model of chronic inflammatory arthritis.

\section{Materials and methods}

Female New Zealand white rabbits (initial weight $1.5-2.0 \mathrm{~kg}$ ) were immunised subcutaneously between the scapulae with $0.5 \mathrm{ml}$ complete Freund's adjuvant $(1 \mathrm{mg} / \mathrm{ml}$ of $M y c o-$ bacterium tuberculosis added to incomplete Freund's adjuvant (Difco)) containing $2.5 \mathrm{mg}$ ovalbumin (Sigma). A booster inoculation was given two weeks later. Four weeks after the booster inoculation the right knee was challenged with an intra-articular injection $(0.5 \mathrm{ml})$ of sterile saline containing ovalbumin $(10 \mathrm{mg} / \mathrm{ml})$. The animals were skin tested before challenge to ensure that the cell mediated immunity was 
evident. The animals were killed by intravenous injection of Sagatal (phenobarbitone sodium (May and Baker)) at least 12 weeks after challenge, at which time the chronic inflammation was well established. ${ }^{13}$ The synovial tissue was removed, cut into suitably sized pieces (up to $0.5 \mathrm{~cm}^{3}$ ), immersed briefly (up to two minutes) in a $5 \%$ aqueous solution of polyvinyl alcohol (Grade G04/140; Wacker) containing $5 \% \mathrm{CaCl}_{2} .2 \mathrm{H}_{2} \mathrm{O}^{18}$ and then chilled to $-70^{\circ} \mathrm{C}$ in $n$-hexane (BDH; grade low in aromatic hydrocarbons). The tissue was stored in dry tubes at $-70^{\circ} \mathrm{C}$ for not longer than two weeks. Sections were then cut at a thickness of $10 \mu \mathrm{m}$ in a Bright's cryostat with the cabinet temperature at or below $-30^{\circ} \mathrm{C}$ and with the knife cooled with solid carbon dioxide packed around its shaft. The sections were flash dried onto slides taken from the ambient temperature of the laboratory ${ }^{18}$ and stored briefly in a dessicator before being tested for enzymatic activity.

\section{HISTOLOGY}

All the blocks of tissue removed from the challenged joints were examined histologically and, depending on the amount of tissue available from each joint, from seven to nine regions were sampled. Sections were stained with $0.1 \%$ toluidine blue in $0.1 \mathrm{M}$ acetate buffer, $\mathrm{pH} 6.1$; others were stained with haematoxylin and eosin and some with methyl green pyronin (all procedures were as described by Chayen $e \mathrm{al}^{18}$ ). The sections were washed, air dried, and mounted in DePeX (BDH).

Three criteria were used for assaying the degree of chronic inflammation: thickening of the synovial cell layer, chronic inflammatory cells, and fibrosis. Each criterion was judged on a scale ranging from 0 to ++ . The degree of inflammation of the whole joint in each challenged joint was then assessed on a scale ranging from - to ++ .

\section{ASSAY FOR UDPGD ACTIVITY}

To determine UDPGD activity, sections were incubated at $37^{\circ} \mathrm{C}$ in a nitrogen atmosphere in medium containing $5.3 \mathrm{mM}$ UDP-glucose (3 $\mathrm{mg} / \mathrm{ml}$; Sigma), $0.45 \mathrm{mM}$ NAD $(0.3 \mathrm{mg} / \mathrm{ml}$; Boehringer) in $30 \%(\mathrm{w} / \mathrm{v})$ polyvinyl alcohol in $0.05 \mathrm{M}$ glycylglycine buffer, $\mathrm{pH} 7 \cdot 8$. The medium was saturated with nitrogen and the $\mathrm{pH}$ adjusted to $\mathrm{pH} 7 \cdot 8$. Just before use $3.7 \mathrm{mM}$ nitro blue tetrazolium $(3 \mathrm{mg} / \mathrm{ml}$; Sigma) was added; in all instances the reaction time was $\mathbf{2 0}$ minutes. To check UDPGD activity (control) serial sections were incubated in medium without substrate (no UDP-glucose) or in full medium including $0.2 \mathrm{mM}$ UDP-xylose $(0.21 \mathrm{mg} / \mathrm{ml}$; Sigma), an inhibitor of UDPGD activity. ${ }^{17}$

After the reaction, sections were washed in water, dried, and mounted in Aquamount (BDH). The precipitated formazan was measured with a Vickers M85A scanning and integrating microdensitometer at a wavelength of $560 \mathrm{~nm}$ in individual cells of the synovial lining, with a $\times \mathbf{4 0}$ objective and a scanning spot of $0.5 \mu \mathrm{m}$ in the plane of the section. At least 10
Table 1 Overall assessment of the degree of inflammation in the antigen challenged joints of each rabbit (overall scale from-to ++). Also shown are the number of pieces of tissue used from each animal in achieving this overall assessment. Scores of ++ and + indicate joints showing appreciable signs of inflammation; \pm indicates those with only minor indications of inflammation

\begin{tabular}{lll}
\hline Rabbit No & $\begin{array}{l}\text { No of blocks } \\
\text { assessed }\end{array}$ & Assessment \\
\hline R1 & 8 & + \\
R2 & 8 & ++ \\
R3 & 7 & \pm \\
R4 & 7 & + \\
R5 & 9 & \pm \\
\hline
\end{tabular}

cells were measured at identical sites in each of two duplicate sections in each assay and up to four different blocks of tissue were used from each animal. The results were converted into units of mean integrated extinction $\times 100$ for a 20 minute reaction time and the results were evaluated by the $t$ test for paired samples.

\section{Results}

HISTOLOGICAL ASSESSMENT

Table 1 shows that the challenged joints from all the animals had some histological evidence of chronic inflammation, ranging from \pm to ++ . Appreciable degrees of inflammation were assessed as + or ++ . Histological examination of the chan.nged joints showed that three had appreciable inflammation, one of which (R2) showed many of the classical changes associated with chronic inflammation. The other two animals had joints which were minimally inflamed.

None of the unchallenged (left side) control joints showed signs of inflammation; all were histologically normal.

\section{UDPGD ACTIVITY IN SYNOVIAL LINING CELLS}

Initially it was necessary to test the validity of the measurements of UDPGD activity. For this, UDPGD activity was measured in sections of blocks from the left (unchallenged) knee of two rabbits and synovial tissue which showed appreciable histological signs of inflammation. Serial sections were reacted in full medium, medium lacking the substrate (UDP-glucose), or full medium with UDP-xylose included. Table 2 shows that sections of uninflamed control synovium from unchallenged joints, reacted in medium lacking the substrate or with UDP-xylose included, gave activities in synovial lining cells of up to 3.6 and $4 \cdot 2 \mathrm{U}$ respectively, against activities in full medium of up to $29 \cdot 8 \mathrm{U}$. The markedly inflamed synovium (from R2) gave values in the medium lacking substrate or the medium with UDP-xylose included, of 3.0 and $4.5 \mathrm{U}$ respectively but gave values of up to only 7.0 $\mathrm{U}$ when incubated in full medium. Thus all the UDPGD activities presented are activities in full medium less the activities measured in the presence of UDP-xylose.

The figure shows the mean values for UDPGD activity for sections from all the blocks investigated from each individual rabbit. In the unchallenged joints the results for UDPGD activity ranged from 14.9 to $22.0 \mathrm{U} /$ cell $(18.0$ 
Table 2 Influence of changes in the reaction medium on the uridine diphosphoglucose dehydrogenase (UDPGD) activity (mean integrated extinction $\times 100(S E M))$ measured in the synovial lining cells of challenged and unchallenged rabbit knee joints (reaction time 20 minutes)

\begin{tabular}{|c|c|c|c|c|}
\hline & Rabbit No & Full medium & No UDPG & Full $+x y$ lose \\
\hline \multirow[t]{2}{*}{ Unchallenged joints } & $\mathrm{R} 3$ & $\begin{array}{l}24 \cdot 4(1 \cdot 1) \\
29 \cdot 8(1 \cdot 1)\end{array}$ & $\begin{array}{l}2 \cdot 4(0 \cdot 2) \\
2 \cdot 6(0 \cdot 2)\end{array}$ & $\begin{array}{l}4 \cdot 2(0 \cdot 2) \\
4 \cdot 1(0 \cdot 2)\end{array}$ \\
\hline & $\mathrm{R} 4$ & $23.4(1.5)$ & $3 \cdot 6(0 \cdot 2)$ & $3.5(0.1)$ \\
\hline Challenged joint & $\mathrm{R} 2$ & $\begin{array}{l}7.0(0.4) \\
6.4(0.3)\end{array}$ & $\begin{array}{l}2.8(0.2) \\
3.0(0.1)\end{array}$ & $\begin{array}{l}3.2(0.2) \\
4.5(0.2)\end{array}$ \\
\hline
\end{tabular}

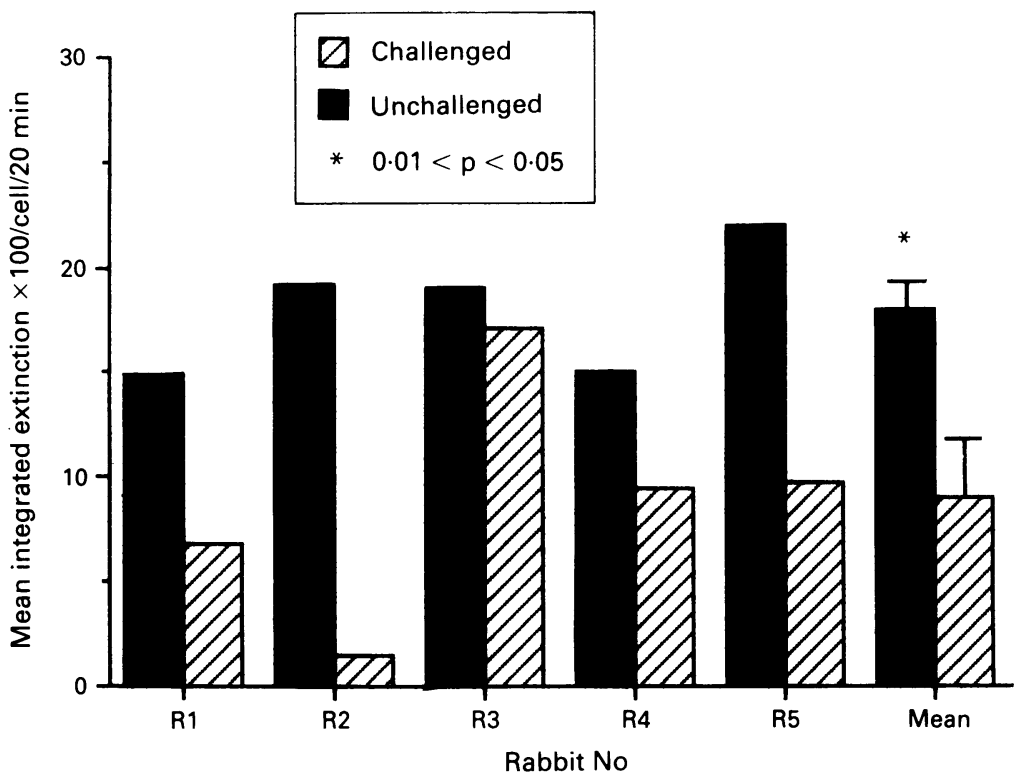

Mean uridine diphosphoglucose dehydrogenase (UDPGD) activity (mean integrated extinction $\times 100 /$ cell $/ 20 \mathrm{~min}$ ) in synovial lining cells in challenged and unchallenged rabbit knee joints. The final pair of columns (mean (SEM)) shows the overall mean UDPGD activity in synovial lining cells from challenged and unchallenged joints $(0 \cdot 01<p<0 \cdot 05)$.

$(3 \cdot 0)$; mean $(\mathrm{SD}))$. In contrast the values in the challenged joints showed considerably greater range, varying from as low as $1.5 \mathrm{U}$ in $\mathrm{R} 2$ up to $17 \cdot 2 \mathrm{U}$ in $\mathrm{R} 3$, and were significantly decreased when compared with the results obtained for the synovial lining cells of the contralateral unchallenged joints $(p<0.03)$. The three animals which had appreciable inflammation as assessed histologically (R1, R2, and R4) had the lowest UDPGD activities of $6 \cdot 8,1 \cdot 5$, and $9 \cdot 4$ when compared with the UDPGD activity in the control unchallenged joints $(p<0 \cdot 01)$. The two animals with minimal inflammation ( $R 3$ and R5) had the highest UDPGD activities in the synovial lining cells in the group of challenged joints, namely $17 \cdot 2$ and $9 \cdot 8 \mathrm{U} /$ cell respectively.

The general appearance of sections of synovium from unchallenged control joints reacted for UDPGD activity showed that the activity (at 20 minutes reaction time) was confined almost exclusively to the surface layer of synovial lining and low, almost negligible, levels of activity were present in the blood vessel walls; the cells deeper in the synovial subintima had negligible levels of UDPGD activity. In synovium from the challenged joints (as discussed earlier) the activity in the histologically accredited lining cells at the synovial surface was greatly reduced, but in some instances a residual level of activity was present in some cells beneath the surface of the synovium.

\section{Discussion}

These results suggest that lining cells in normal non-inflamed synovium have the enzymatic machinery necessary for the synthesis of glycosaminoglycans and particularly hyaluronan and that this may be an indication of a specific part played by these cells in the maintenance of normal joint function. Previously De Luca et al ${ }^{19}$ showed, using enzymes isolated from newborn pig epiphysial plate cartilage and from bovine cornea, that UDPGD activity had a central role in the nature of the monosaccharides produced from the utilisation of UDP-glucose, suggesting that it may be a key branchpoint in the synthesis of glycosaminoglycans. Furthermore it has been suggested that UDPGD activity is the irreversible ${ }^{9}$ rate limiting step in the synthesis of UDP-glucuronate, ${ }^{10}$ which is essential as a monosaccharide in the production of hyaluronan and chondroitin sulphates. Biochemical studies of UDPGD activity in cells isolated from synovium and maintained in vitro showed that cells cultured from normal and rheumatoid arthritic synovium had similar UDPGD activity for each unit mass of protein. $^{20}{ }^{21}$ These workers point out, however, that there are some limitations to the conclusions which can be drawn from cultures of cells isolated from a heterogeneous tissue such as synovium and that as stressed earlier normal and chronically inflamed synovial membranes are not suitable for conventional biochemical investigation.

Using a newly adapted quantitative cytochemical method ${ }^{17}$ for the assessment of UDPGD activity in situ, we have shown that individual synoviocytes in chronically inflamed synovium from challenged rabbit knee joints show a marked decrease in UDPGD activity compared with the synovial lining cells of the contralateral (unchallenged) normal joints. In addition, the results suggest that there is a direct agreement between the degree of inflammation as assessed histologically and the decrease in UDPGD activity in the lining cells in the challenged knees.

Furthermore, it has been shown that increasing the ratio of NADH relative to NAD appeared to inhibit the activity of UDPGD which had been isolated from epiphysial plate cartilage and that the inhibition of UDPGD activity was most marked when the enzyme was assayed at $\mathrm{pH}$ values approaching neutrality. ${ }^{22}$ These workers suggest that there is a direct relation between the nature of the glycosaminoglycan precursors synthesised (with UDPGD activity at a key pivotal point) and the redox state of the cell. ${ }^{23}$ In addition, earlier cytochemical studies on tissue removed from human rheumatoid arthritic joints have shown that there was a fourfold increase in glucose 6-phosphate dehydrogenase activity, which generates NADPH, and a considerably more reductive balance in the cellular -SH:-S-S - ratio in synovial lining cells. $^{24} 25$ These workers also showed that human non-rheumatoid synovium could be maintained in vitro in organ maintenance culture at $\mathrm{pH} 7.8$ but that it died at $\mathrm{pH}$ values of $7 \cdot 4$ or below. In contrast human rheumatoid synovium did not survive at $\mathrm{pH}$ values above 
$7 \cdot 4 .^{26}$ The preference for a more acid environment shown by the rheumatoid tissue is in keeping with the fact that synovial fluid from human rheumatoid joints has been reported to be more acidic than the fluid from non-rheumatoid joints. ${ }^{27} 28$ Considering these findings it may be possible to postulate that the conditions found within the chronically inflamed joint, namely a more reductive balance and a $\mathrm{pH}$ approaching neutrality, are such as to produce a marked decrease of UDPGD activity within the cells lining the synovium, leading to alterations in the synthesis of glycosaminoglycans which may be central to the maintenance of normal joint function.

We are grateful to the Arthritis and Rheumatism Council for providing the funding for this project. This work was carried out while the authors were working in the Division of Cellular Biology, Kennedy Institute of Rheumatology, Hammersmith, London, United Kingdom.

1 Fraser I R E, Laurent T C. Turnover and metabolism of hyaluronan. In: The biology of hyaluroman. London: Wiley 1989: 41-59. (Ciba Foundation Symposium, No 143.)

2 Hutodolik N, Gosh P, Brooks P M. Binding of haptoglobin inter-alpha-trypsin and alpha-1 proteinase to synovial fluid hyaluronate and the influence of these proteins on its degradation by oxygen derived free radicals. Ann Rheum Dis 1988; 47: 377-85.

3 Ropes M W, Bauer W. Synovial fluid changes in joint disease. Cambridge: Harvard University Press, 1953.

4 Balazs E A, Watson D, Duff I F, Roseman S. Hyaluronic acid in synovial fluid. 1 . Molecular parameters of hyaluronic acid in normal and arthritic human fluids. Arthritis Rheum 1967; 10: 357-75.

5 Yielding K L, Tomkins G M, Bunim J J. Synthesis of hyaluronic acid by human synovial tissue slices. Science 1957; 125: 1300 .

6 Henderson B, Edwards J C W. The symovial lining: in health and disease. London: Chapman and Hall, 1987.

7 Laurent T. Introduction. In: The biology of hyaluroman. London: Wiley 1989: 1-5. (Ciba Foundation Symposium, No 143.)

8 Prehm P. Synthesis of hyaluronan in differentiated teratocarcinoma cells. II. Mechanism of chain growth. Biochem $\mathcal{f}$ 1983; 211 : 191-8.

$9 \mathrm{Molz}$ R J, Danishefsky I. Uridine diphosphate glucose dehydrogenase in rat tissue. Biochim Biophys Acta 1971; 250: 6-13.
10 McGarry A, Gahan P B. A quantitative cytochemical study of UDP-D-glucose:NAD-oxidoreductase (E.C.1.1.1.22) activity during stellar differentiation in Pisum sativum $\mathbf{L}$. cv Meteor. Histochemistry 1985; 83: 551-4.

11 Chayen J. Quantitative cytochemistry: a precise form of cellular biochemistry. Biochem Soc Trans 1984; 12: 887-98.

12 Dumonde D C, Glynn L E. The production of arthritis in rabbits by an immunological reaction to fibrin. $\operatorname{Br} \mathcal{F} \operatorname{Exp}$ Pathol 1962; 43: 373-83.

13 Consden R, Doble A, Glynn L E, Nind A P. Production of chronic arthritis with ovalbumin. Ann Rheum Dis 1971; 30: 307-15.

14 Chayen J, Bitensky L. Metabolism of rheumatoid and nonrheumatoid synovial lining. In: Franchimont $P$, ed. Articular synovium. Basle: Karger, 1982: 59-74.

15 Henderson B, Glynn L E. Metabolic alterations in the synoviocytes in chronically inflamed knee joints in immune arthritis in the rabbit: comparison with rheumatoid arthritis. Br f Exp Pathol 1981; 61: 27-34.

16 Pitsillides A A, Blake S M, Glynn L E, Bitensky L, Chayen J. Amelioration by menadione of experimental chronic immune arthritis in the rabbit. Cell Biochem Funct 1990; 8: 221-6.

17 Mehdizadeh S, Bitensky L, Chayen J. The assay of uridine diphosphoglucose dehydrogenase activity. Cell Biochem Funct 1991; 9: 109-17.

18 Chayen J, Bitensky L, Butcher R G. Practical histochemistry. New York, London: Wiley, 1973.

19 De Luca G, Speziale P, Balduinin C, Castellani A A. Biosynthesis of glycosaminoglycans: uridine diphosphate 4epimerase from cornea and epiphysial-plate cartilage. Connect Tissue Res 1975; 3: 39-47.

20 Ross G T, Marsh J M, Roback D W. Uridine diphosphate glucose dehydrogenase in normal synovial lining cells in culture. F R heumatol 1979; 6: 489-96.

21 Ross G T, Marsh J M, Roback D W. Uridine diphosphate glucose dehydrogenase in rheumatoid synovial lining cells in culture. $\mathcal{F}$ Rheumatol $1981 ; 8: 710-5$.

22 De Luca G, Castellani A A. Regulatory aspects of glycosaminoglycan biosynthesis. Acta Biol Hung 1984; 35: 109-21.

23 De Luca G, Speziale P, Rindi S, Balduini C, Castellani A A. Effect of some nucleotides on the regulation of glycosaminoglycan biosynthesis. Connect Tissue Res 1976; 4: 247-54.

24 Butcher R G, Bitensky L, Cashman B, Chayen J. Differences in the redox balance in human rheumatoid and nonrheumatoid synovial lining cells. Beitrage zur Pathologie rheumatoid synovial

25 Chayen J, Bitensky $\mathrm{L}$. The effects of pharmacologically active agents on cytosolic reducing equivalents. Reviews of Pure and Applied Pharmaceutical Science 1982; 3: 271-317.

26 Poulter L W, Bitensky L, Cashman B, Chayen J. The maintenance of human synovial tissue in vitro. Virchows Arch (Zellpath) 1970; 4: 303-9.

27 Barnett C H, Davies D V, MacConail M M. Synovial joints: their structure and mechanics. London: Longmans, 1961.

28 Cummings N A, Nordby G L. Measurement of synovial fluid $\mathrm{pH}$ in normal and arthritic knees. Arthritis Rheum 1966; 9: 47-56. 